Original Research Paper

\title{
Lead Phytotoxicity Induced Changes in Biochemical Markers in Germination and Seedlings in Durum Wheat Triticum durum Desf. Cv.Vitron and Gta
}

\author{
${ }^{1}$ Soraya Slimani, ${ }^{1}$ Mokhtar Boudelaa, ${ }^{2}$ Saddek Abdelmadjid, \\ ${ }^{1}$ Ali Ladjama, ${ }^{1}$ Imène Nedjah and ${ }^{1}$ Mounia Benkaddour \\ ${ }^{1}$ Laboratory of Applied Biochemistry and Microbiology, University of Badji Mokhtar-Annaba, Annaba 23000, Algeria \\ ${ }^{2}$ Department of Biology, University of Mohamed Cherif Messaadia, Souk Ahrass 41000, Algeria
}

Article history

Received: 24-02-2016

Revised: 20-03-2017

Accepted: 11-05-2017

Corresponding Author: Soraya Slimani

Laboratory of Applied

Biochemistry and

Microbiology, University of

Badji Mokhtar-Annaba,

Annaba 23000, Algeria

E-mail: Soramy2000@yahoo.fr

\begin{abstract}
Among the heavy metals most commonly found on land, lead is a strongly represented pollutant in soil and sediments. It is easily absorbed and accumulated in different parts of plants. On the macroscopic scale, lead causes unfavorable effects on plants. First and in the event of excess, it may exert toxicity affecting several stages of germination development in leaf formation and root elongation in the early stages of development. The effect of lead on two varieties of durum wheat Triticum durum cv Gta and Vitron have been analyzed on germination under laboratory conditions. The objective is to determine the influence of lead on (i) germinal parameters and (ii) the stress physiological markers. The experiment was set up in a completely randomized design with 3 replications of 20 seeds per variety, including 4 concentrations of $\mathrm{Pb}\left(\mathrm{NO}_{3}\right)_{2}(0,320,430$ and 660 ppm) on the germination. Average ambient temperature was $22^{\circ} \mathrm{C}$, the humidity was $32 \%$ and photoperiod light/dark was $16 / 8 \mathrm{~h}$. The obtained results showed a real sensitivity of germination to lead. Indeed, it was noted a total absence of germination of the two varieties in all seeds treated with the highest concentration. The treatment of seeds by the increasing doses of lead decreased the germinative faculty considerably, the content of pigments and disrupted the cellular metabolism, the proteins, the proline and glutathione levels. These results indicated that lead stress caused a decrease in germinal parameters and significant impairment of cell biochemical markers. Such effect was inversely proportional to the doses used. It was also noted that the Gta variety was less sensitive to lead toxicity than Vitron.
\end{abstract}

Keywords: Lead, Germination, Wheat, Pigment, Protein, Proline, Glutathione

\section{Introduction}

Heavy metals enlist a relatively series of elements with the specific density over $5 \mathrm{~cm}^{3}$ (Kozlowski et al., 2003) and the relative atomic mass above 40 (Raskin et al., 1994). These metallic elements are toxic and naturally found in the environment at low concentrations (Siddiqui et al., 2014).

Lead is very widespread in Algeria, it is found in many industrial and agricultural factories, such as mining, fertilizers, pesticides and also the manufacture of automobile batteries, in addition to big number of cars realizing huge amounts of lead into the environment.
Besides, Algeria is amongst the country using lead in gasoline to improve octane combustion, where its level in oil is in the order of $0.45 \mathrm{~g} \mathrm{~L}^{-1}$ (Semmadi, 1989) Moreover, it has been shown that the level of atmospheric $\mathrm{Pb}$ near the highways is around $140 \mathrm{~kg}$ $\mathrm{Pb}$ /day (Semmadi, 1989). Soil contamination by heavy metals is a natural phenomenon which has become widespread as a result of agricultural and industrial practices of anthropogenic activities. Lead is easily absorbed and accumulated in different parts of the plants including root, shoot, fruit and grain (Sharma and Shanker, 2005) and causes a serious disorder in plant and animal communities by being inserted into the food 
chain and exerting high toxicity (Adriano, 2001; Alkorta et al., 2004; Behanzin et al., 2015). At the cellular level, it can affect respiration, photosynthesis, water and mineral absorption, (Nagajyoti et al., 2010), causes oxidative stress and disrupt the activity of various enzymes which are very important for the cellular metabolism (Singh et al., 1997; Viehweger, 2014).

At the macroscopic level, low concentrations of lead inhibited germination strongly (Mishra and Chaudhuri, 1998; Tomulescu et al., 2004). Also, at higher doses, it inhibited the germination of beans completely (Wierzbicka and Obidzinka, 1998). Lead also reduces significantly the development of seedlings and sprouts (Mishra and Chaudhuri, 1998). In Algeria, since the government has subsidized the cultivation of cereals as that of wheat, some farmers are growing this plant near lead pollution sources, ignoring however, its risk to human health.

The objective of this work is to investigate the lead toxicity on germination, which is one of the fundamental stages in the plant life and crop production. However, two cultivars of durum wheat Triticum durum cv. Gta and Vitron have been grown in the laboratory conditions. Thus, germination parameters and the stress physiological markers were evaluated.

\section{Materials and Methods}

The plant material studied consists of two varieties of durum wheat Triticum durum Desf cv. Gta and Vitron. 20 seeds per variety are germinated in $8.5 \mathrm{~cm}$ diameter petri dishes on blotting paper (Whatman) after a $24 \mathrm{~h}$ pre-imbibition to facilitate germination. The test was carried out under standard laboratory conditions, according to a completely randomized 3repeat procedure and 4 concentrations of $\mathrm{Pb}\left(\mathrm{NO}_{3}\right)_{2}$ added to the germination medium $(0,330,430$ and $660 \mathrm{ppm})$. Treatment with solutions containing lead was made at a rate of $25 \mathrm{~mL}$ per concentration. The average ambient temperature is $22^{\circ} \mathrm{C}$, the humidity is $32 \%$ and the light/dark photoperiod is $16 / 08 \mathrm{~h}$.

\section{The Germination Capacity}

The germinative capacity is determined by the ratio of the number of germinated seeds to the total number of seeds germinated multiplied by 100 (Shirafew and Baker, 1996).

\section{Dosage Pigments}

After extraction, by the uses of Dimethyl Sulfoxide (DMSO) as solvent without maceration of the leaves (Hiscox and Israelsam, 1979), the chlorophylls and carotenoids pigments are determined by reading their absorbance at wavelengths between 400 and $700 \mathrm{~nm}$ and then the contents of chlorophylls (a) and (b) $\mu \mathrm{g} / \mathrm{g}$ of fresh weight (fw) were obtained, according to the equations of Arnon and Inney (1949).

\section{Proteins Assay}

Total proteins were determined by the method of Bradford (1976). A sample of $500 \mathrm{mg}$ of fresh leaves was ground and homogenized in $1 \mathrm{~mL}$ of phosphate buffer $(\mathrm{pH}=7.0)$ and then centrifuged at $5000 \mathrm{t} / \mathrm{min}$ for $10 \mathrm{~min}$. Then $50 \mathrm{~mL}$ of previously prepared Trichloroacetic Acid (TCA) was added and a second centrifugation was carried out at $8000 \mathrm{rpm}$ for $15 \mathrm{~min}$. The debris was dissolved in $1 \mathrm{~mL}$ of $0.1 \mathrm{~N} \mathrm{NaOH}$ and $5 \mathrm{~mL}$ of Bradford reagent was added. The Optical Density (OD) of the samples is read at $595 \mathrm{~nm}$ and then the content of the proteins is determined using a calibration curve containing bovine serum albumin.

\section{Dosage of Proline}

To determine the proline content, a sample of 500 $\mathrm{mg}$ of fresh plant tissue was ground in $3 \%(\mathrm{w} / \mathrm{v})$ aqueous sulfosalicylic acid and then centrifuged at $5000 \mathrm{rpm}$. The proline of the supernatant was estimated by the ninhydrin reagent (Bates et al., 1973). Reading of the absorbance of the fraction with toluene aspirated from the liquid phase was read in a spectrophotometer at $520 \mathrm{~nm}$.

\section{Determination of Glutathione}

The glutathione content is determined by the method of Weckbeker and Cory (1988). Thus, $250 \mathrm{mg}$ sample of each concentration was cold milled in a mortar with $2 \mathrm{ml}$ of buffer solution $(\mathrm{pH}=6.5)$ placed in the centrifuge at a $5000 \mathrm{t} / \mathrm{min}$ for 15 minutes. The supernatant was recovered by filtration. Then $0.8 \mathrm{~mL}$ of the supernatant was taken and $0.2 \mathrm{~mL}$ of Sulfosalicylic Acid (SSA) $0.25 \%$ solution was added, stirred and then it left for $15 \mathrm{~min}$ in an ice bath and immediately centrifuged at $1000 \mathrm{~g} / \mathrm{min}$ for $5 \mathrm{~min}$.

The assay: The reaction medium consists of 0.5 $\mathrm{mL}$ of the supernatant (enzyme extract) $1 \mathrm{~mL}$ TrisEDTA buffer (0.02 M EDTA) and $0.25 \mathrm{~mL}$ of DTNB. The whole mixture is vortexed and left for $5 \mathrm{~min}$ at room temperature to the stabilization of the color that develops instantaneously.

The glutathione content was determined pat reading (OD) at $412 \mathrm{~nm}$. The calibration of the spectrophotometer is carried out by a solution containing $0.5 \mathrm{~mL}$ distilled water, $1 \mathrm{~mL}$ Tris-EDTA and $0.25 \mathrm{~mL}$ DTNB. The concentration of glutathione is obtained by the formula:

$$
\mathrm{GSH}=(\mathrm{OD} \times 1 \times 1.525) /(13.1 \times 0.8 \times 0.5 \mathrm{mg} \text { protein })
$$

Or:

- GSH: Glutathione concentration in $\left(\mathrm{nM} \cdot \mathrm{mg}^{-1}\right.$ of protein)

- OD: Optical density at $412 \mathrm{~nm}$ 
- 1: Total volume of the solutions used in the deproteinization $(0.8+0.2 \mathrm{~mL}$ supernatant SSA)

- 1.525: Total volume of the solutions used in the assay of GSH $(0.5 \mathrm{~mL}$ supernatant, $1 \mathrm{ml}$ Tris-EDTA +0.25 mL DTNB)

- 13,100: Absorbance coefficient of the group (SH) at $412 \mathrm{~nm}$

- 0.5 : Volume of the float found in $1.525 \mathrm{~mL}$

- 0.8 : Volume of the homogenate found in $1 \mathrm{~mL}$

It is noted that the GSH concentration is measured by the addition of $1 \mathrm{mg}$ of proteins. That is why this dosage must be accompanied by protein assay.

\section{Statistical Analysis}

All the results of this work were statistically treated by the analysis of variance with 2 criteria of classification to $\alpha=5 \%, \alpha=1 \%$ and $\alpha=0.1 \%$ by the use of Minitab reference manual (1998).

\section{Results}

\section{Germination Capacity}

The effect of lead on germination of the two wheat varieties Gta and Vitron were studied. The obtained results (Fig. 1) show that in control groups the seeds were viable and had a good faculty. Indeed, the fifth day, all seeds had reached a maximum germination $(>95 \%)$. However, we noticed that lead exerted a negative and significant action on germination process and its success $(p<0.01)$ (Table 1$)$. There was a total absence of germination in all seeds of both varieties treated with the highest concentrations of $660 \mathrm{ppm}$.

\section{Chlorophyll and Carotenoids Content}

The results showed that total chlorophyll content in leaves of seedlings in control plants have reached the

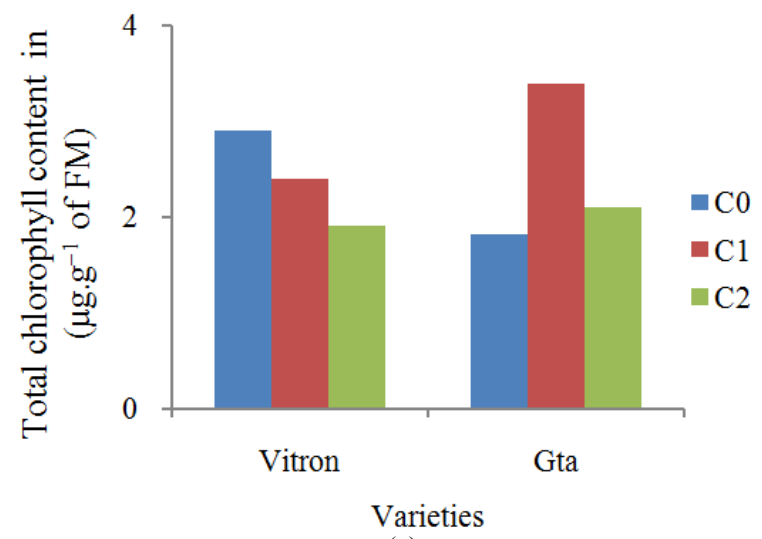

(a) maximum level in Vitron cultivar. The content varies depending on the variety, the $\mathrm{Pb}$ concentration and the type of pigment. Indeed, seed treatment with lead appears to stimulate slightly the total synthesis of the total chlorophyll in the Gta variety (Fig. 2a) and inhibit it in the Vitron variety. Furthermore, concerning the carotenoids content (Fig. 2b), $\mathrm{Pb}$ decreased it in the Vitron variety and increased it in the Gta, especially in the seeds treated with $(430 \mathrm{ppm})$. In the control groups, it was noticed that the first variety had more carotenoids than Gta one (Table 1).

\section{Protein Content}

The effect of $\mathrm{Pb}$ on protein content is presented in Fig. 3. Protein content was high in the Vitron variety $(0.50 \mu \mathrm{g} / \mathrm{g} . \mathrm{fw})$ than its counterpart of Gta $(0.30 \mu \mathrm{g} / \mathrm{g} . \mathrm{fw})$. Contrary, it is reported that in the latter variety, the seed treatment by lead decreased to a very highly significant protein synthesis in young seedlings (Table 1), especially those treated with $330 \mathrm{ppm}$. Conversely, for Vitron, $\mathrm{Pb}$ appears to exert no significant effect on this parameter.

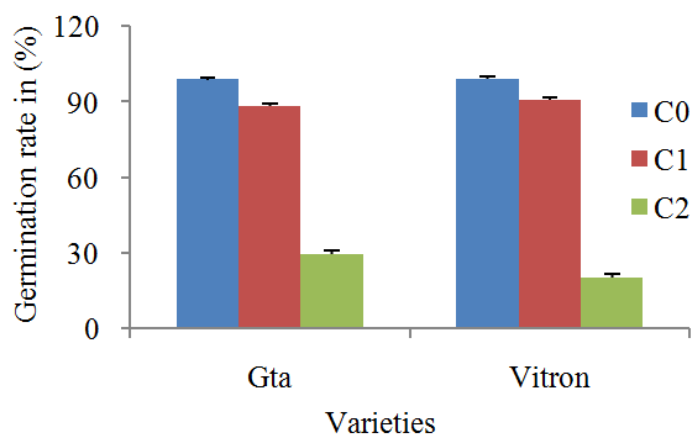

Fig. 1. Effect of lead on wheat germination capacity. $\mathrm{C}_{0}: 0$ ppm control without treatment. $\mathrm{C}_{1}: 320 \mathrm{ppm}, \mathrm{C}_{2}: 430$ ppm, $\mathrm{C}_{3}: 660 \mathrm{ppm}$ for 1 week

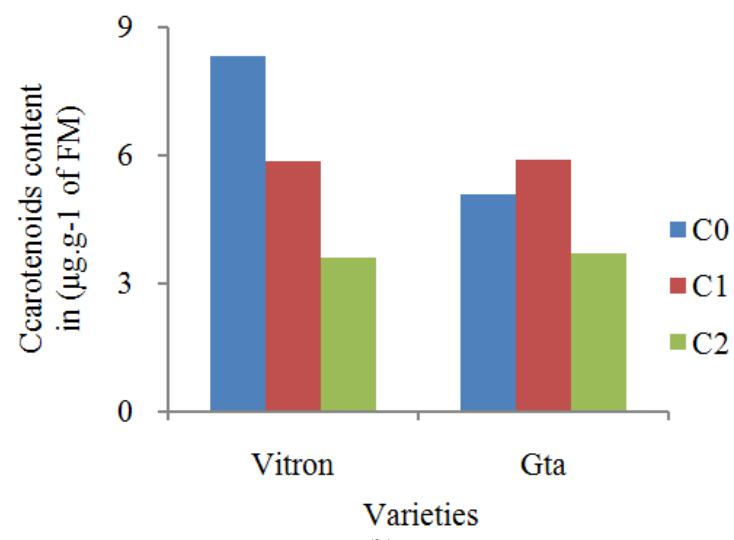

(b)

Fig. 2. Effect of lead on wheat pigment content during seedlings. $\mathrm{C}_{0}: 0 \mathrm{ppm}$ control without treatment. $\mathrm{C}_{1}: 320 \mathrm{ppm}, \mathrm{C}_{2}: 430 \mathrm{ppm}$, $\mathrm{C}_{3}: 660$ ppm for 1week. (a) Chlorophylls; (b) Carotenoids 
Table. 1. Values of the F observed (Fobs) of the variance analysis 2 classification criteria of the studied parameters

\begin{tabular}{llllllll}
\hline S var & d.d.1 & GC en $(\%)$ & Total Chl & Carotenoids & Proteins & Proline & Glutathione \\
\hline Con & 2 & $8960.13^{* * *}$ & $22.22^{* * *}$ & $96.49^{* * *}$ & $15.66^{* * *}$ & $0.91 \mathrm{~ns}$ & $3.95^{*}$ \\
Var & 1 & $24.93^{* * *}$ & $0.10 \mathrm{~ns}$ & $32.51^{* * *}$ & $1.70 \mathrm{~ns}$ & $0.63 \mathrm{~ns}$ & $0.07 \mathrm{~ns}$ \\
Interaction & 2 & $55.28^{* * *}$ & $24.48^{* * *}$ & $38.27^{* * *}$ & $8.78^{* *}$ & $1.0 \mathrm{~ns}$ & $2.52 \mathrm{~ns}$ \\
Error & 18 & & & & & \\
Total & 23 & & & & & & \\
\hline
\end{tabular}

S var: Source of variation; d.d.l: Degree of freedom; GC: Germination Capacity; $\left({ }^{*} p<0.05\right.$ : Significant, **p<0.01: High significant, $* * * p<0.001$ : Very high significant)

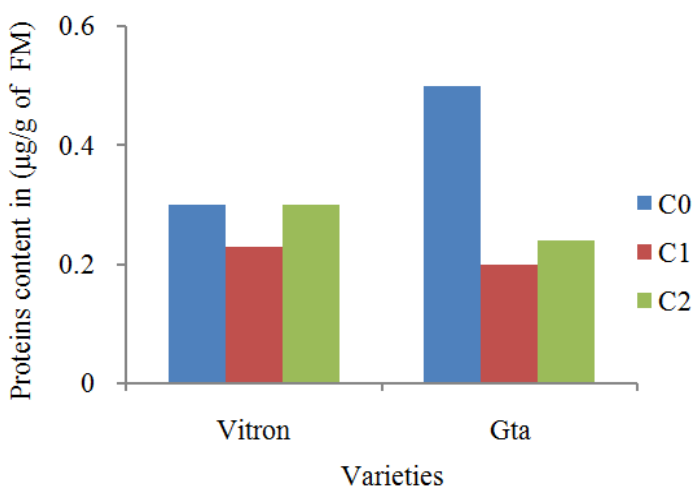

Fig. 3. Effect of lead on protein content of wheat seedlings. $\mathrm{C}_{0}$ : $0 \mathrm{ppm}$ control without treatment. $\mathrm{C}_{1}: 320 \mathrm{ppm}, \mathrm{C}_{2}: 430$ ppm, $\mathrm{C}_{3}: 660 \mathrm{ppm}$ for 1 week

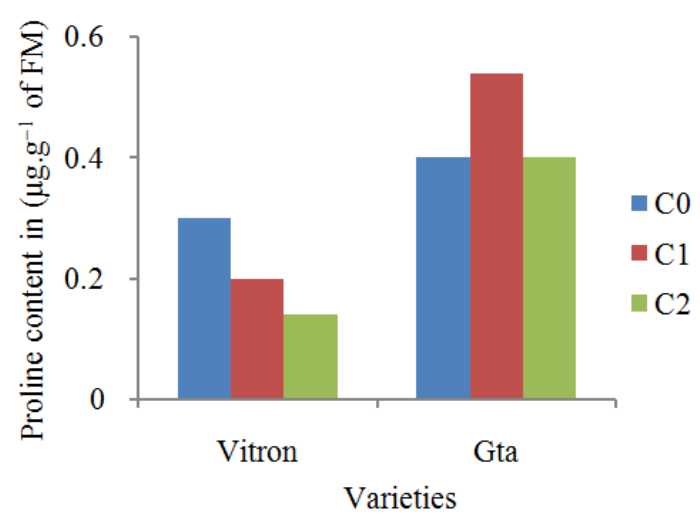

Fig. 4. Effect of lead on proline content in wheat seedlings. $\mathrm{C}_{0}$ : $0 \mathrm{ppm}$ control without treatment. $\mathrm{C}_{1}: 320 \mathrm{ppm}, \mathrm{C}_{2}: 430$ ppm, $\mathrm{C}_{3}: 660 \mathrm{ppm}$ for 1 week

\section{Proline Content}

The results related to lead effect on proline content (Fig. 4) showed that the Gta variety contains more free amino acid, the proline than the Vitron variety $(0.44$ against $0.3 \mu \mathrm{g} / \mathrm{g} . \mathrm{fw})$, respectively. Contrary, in lead treated seeds, a slight stimulation but not significant (Table 1) of proline synthesis in the Gta variety $(0.54 \mu \mathrm{g} / \mathrm{g}$.fw) was noted and caused by $330 \mathrm{ppm}$ concentration, accompanied with a reduction of proline in the Vitron variety. The effect was inversely proportional to the applied doses, respectively 0.2 and $0.14 \mu \mathrm{g} / \mathrm{g}$.fw for the concentration of 330 and $430 \mathrm{ppm}$.

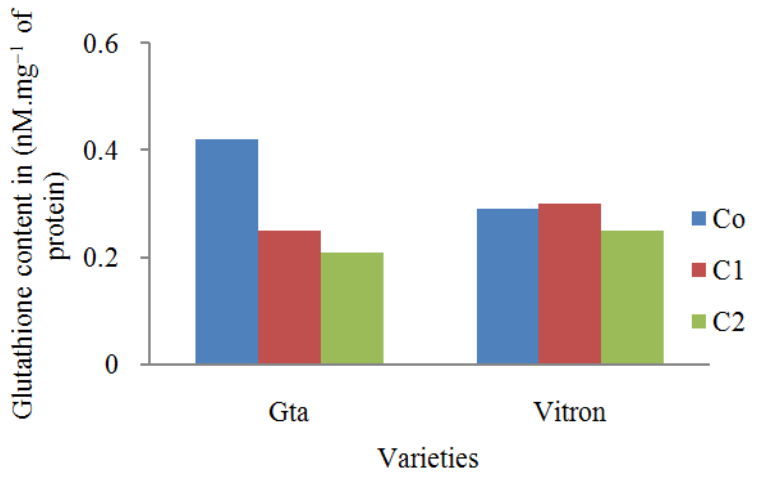

Fig. 5. Effect of lead on glutathione content in wheat seedlings. $\mathrm{C}_{0}: 0$ ppm control without treatment. $\mathrm{C}_{1}: 320 \mathrm{ppm}, \mathrm{C}_{2}$ : $430 \mathrm{ppm}, \mathrm{C}_{3}: 660 \mathrm{ppm}$ for 1 week.

\section{Glutathione Content (GSH)}

The observation in (Fig. 5) shows that the Gta variety has more glutathione than Vitron (almost one and a half) in the controls $\left(0.42 \mathrm{nM} \mathrm{GSH} . \mathrm{mg}^{-1}\right.$ protein against 0.29 nM GSH. $\mathrm{mg}^{-1}$ protein). On the other hand, seed treatment by different concentrations of lead nitrate $\left(\mathrm{PbNO}_{3}\right)_{2}$ induced a significant decrease in the glutathione content $(p<0.05)$, (Table 1) for all levels in both varieties.

\section{Discussion}

This study shows the depressive effect of lead on the germination phenomenon of durum wheat Triticum durum, cv. Gta and Vitron. These results are similar to other works cited in the literature and found by Chatterjee et al. (2004) who observed the same effect of high lead levels on rice seeds. Accordingly, the work of Seregin and Ivanov (2001) on Phaseolus vulgaris and Pisum sativum seeds has proved that these species are now considered to be susceptible to heavy metals, which do not germinate even in very low concentrations. The same effects were observed on the germination of Brassica perkinensis (Xiong, 1997), carrot and radish (Chen et al., 2002). All these studies have shown that lead is able to reduce germination, coleoptiles growth and the number of sprouts per seed cultivated plant species.

Furthermore, in regard to the lead effect on the leaf pigments, identical results have been found by researchers like Padjama et al. (1990; Moreno-Casseles et al., 2000; 
Kosobrukhov et al., 2004; Qureshi et al., 2005; Chen et al., 2007; Gopal and Rizvi, 2008) who noted a disturbance in pigments contained in the leaves of young plants grown from seeds treated with heavy metals. In addition, chlorophyll (b) appears to be more sensitive than chlorophyll (a) (Wozny et al., 1995; Vodnik et al., 1999). However, these effects vary among plant species. The reduction mechanisms of synthesized pigments can be explained by the inactivation of pigment synthesis by inhibition of the enzyme system which is implicated as $\delta$ aminolevulinate dehydratase or ALAD and protochlorophyllide reductase (Padjama et al., 1990; Van Assche and Clijsters, 1990) or by substituting for divalent ions associated with metallo-enzymes. The supply of $\mathrm{Mg}^{2+}, \mathrm{Fe}^{2+}$ and $\mathrm{Zn}^{2+}$ (Van Assche and Clijsters, 1990; Krupa and Bazynski 1995), which is the basis of the synthesis of chlorophyll and $\mathrm{Zn}^{2+}$ ion which can be replaced by $\left(\mathrm{Pb}^{2+}\right)$ or ii), an indirect way, by inducing a deficiency of these divalent ions. An identical decrease in chlorophyll content induced by metal stress was reported earlier in plants such as Picea abies, Zea mays, Quercus palustrus, Acer rubrum and Helianthus annus.

However, concerning carotenoids, it was found that the Vitron variety contains more carotenoids than the Gta variety in the control groups. By contrast, in the $\mathrm{Pb}$ treated seeds, it was noted a relatively high concentration in the Gta compared to its control. This increase in concentration is probably a positive reaction to counteract stress and reduce its effect. It is known that this class of pigments plays a key role in eliminating free radicals, which allow the removal of lipid peroxides (Palozza and Krinsky, 1999), or by the physical deactivations of singlet oxygen, especially in the case of lycopene (Sandquiest et al., 1994).

With regard to the amino acid proline, the results are in almost identical to those found by Chen et al. (2002) which indicate that the proline content increases when treatment doses were low and decreases drastically when they were high. Note that proline is a good indicator of environmental stress. It is considered a non-specific agent of the plant defense system against the toxicity of heavy metals and plays several protecting roles (Sharma and Dubey, 2005) including the inhibition of lipid peroxidation (Mehta and Gaur, 1999), attachment of free radicals (Alia and Matysik, 2001) and also as a metal chelating agent (Fargo and Mullen, 1979). The explanation for the rise in proline content in seeds treated with high concentrations is the formation of a non-toxic complex (Proline-Pb) by chelating lead ions, which is considered a detoxification mechanism. Moreover, treatment of seeds with elevated levels of heavy metals induce changes at the molecular level that affect the essential physiological functions and metabolism is disrupted by blocking and inhibiting the enzymatic activity regulating synthesis reactions.
Concerning proteins and glutathione, it was noted that the $\mathrm{Pb}$ toxicity induced an increase of these markers in leaf mesophyll tissue of lead treated seeds. This is certainly due to an induction of these biochemical markers caused by the effect of exposure to metal stress (Mesmar and Jaber, 1991). The protein content was increased in plants of the variety Vitron treated with the highest dose and remained stable compared to control of other concentrations. These results are supported by Mohan and Hosetti (1997; Saxena et al., 2003; Mishra et al., 2006), which indicate that heavy metals induce an increases in the content of glutathione and protein with low doses. The action of lead on the protein content shows that high concentrations can reduce protein content. Their synthesis is slowed or even inhibited (Chen et al., 2002; Chatterjee et al., 2004). This reduction appears as a result of the consequences of the action of lead, such as decreased or stimulated protease activity and/or decreased free amino acid content (Xiong et al., 2006). Furthermore, lower concentrations seem, on the contrary to increase total protein content (Mishra et al., 2006). This protein accumulation may be the result of the synthesis by the plant defense system against this metal, or in the sequestration of metal by glutathione to neutralize the high concentrations of $\mathrm{Pb}$ (Rauser, 1999; Mourato et al., 2015).

In this context, the treatment of plants by lead has caused a rise of glutathione content in both varieties regardless of the concentration used. This is, because glutathione can contribute to the synthesis of phytochelatins, which appear to play an important role in the detoxification and tolerance of plants to lead (Gupta et al., 1995; Piechalak et al., 2002). These PCs have the main role of sequestering and/or chelating lead and some heavy metals in the cytoplasm (Barrameda-Medina et al., 2014) before transport and final isolation in the vacuoles so as not to interfere with cellular metabolism (Piechalak et al., 2002; Seregin et al., 2002; Małecka et al., 2008).

In general manner, the high concentrations of heavy metals induces changes at the molecular level that affect the essential physiological functions where the metabolism is damaged by blocking and inhibiting the enzymatic activity governing the synthesis reactions (Wolinska et al., 1980). However, there was also a slight stimulation caused by low lead concentration (Ernst et al., 1992). This stimulation is due to the activation of cell metabolism such as the uptake of $\mathrm{O}_{2}$ in tobacco leaves (Prasad and Hagemeyer, 1999; Prassad et al., 2001) where an increase in the activity of PSII (photosynthetic activity) was observed (Baszynski and Tukendorf, 1991; Krupa and Bazynski, 1995)

\section{Conclusion}

The results obtained indicate that the treatment of wheat seeds by lead show that the germination 
phenomenon has been altered, as well as the amino acid proline, the tripeptide glutathione, the proteins and also the photoreceptor pigments.

The comparison of these cultivars with the effect of the lead makes appear that the Gta variety was less sensitive than Vitron. The effect of lead on the parameters studied was inversely proportional to the doses used in the treatment.

\section{Acknowledgment}

The authors cordially thank Professor C. Abdenour for their help in correcting and improving the article in English.

\section{Author's Contributions}

You can see the "Authors and Contribution Declaration for a Scientific Publication"

\section{Ethics}

The authors state that there is no conflict of interest and that is a research team task.

\section{References}

Adriano, D.C., 2001. Trace Metals in Terrestrial Environments: Biogeochemistry, Bioavailability and Risk of Metals. 2nd Edn., Springer-Verlag, New York, pp: 866.

Alia, M.P. and J. Matysik, 2001. Effect of proline on the production of singlet oxygen. Amino Acids, 21: 195-200. DOI: $10.1007 / \mathrm{s} 007260170026$

Alkorta, I., J. Hernandez-Allica, J.M. Becerril, L. Amezaga and L. Albizu et al., 2004. Recent findings on the phytoremediation of soils contaminated with environmentally toxic heavy metals and metalloids such as zinc, cadmium, lead and arsenic. Environ. Sci. Biotechnol., 3: 71-90.

DOI: 10.1023/B:RESB.0000040059.70899.3d

Arnon, D.L. and M. Kinny, 1949. Copper enzymes in isolated chloroplasts polyphenoloxidase in Beta vulgaris. Plant Physiol., 34: 1-15. DOI: $10.1104 /$ pp.24.1.1

Barrameda-Medina, Y., D. Montesinos-Pereira, L. Romero, B. Blasco and J.M. Ruiz, 2014. Role of GSH homeostasis under $\mathrm{Zn}$ toxicity in plants with different Zn tolerance. Plant Sci., 227: 110-121. DOI: 10.1016/j.plantsci.2014.07.010

Baszynski, T. and A. Tukendorf, 1991. The in vivo effect of cadmium on photochemical activities in chloroplasts of runner bean plants. Acta Physiol. Plant., 13: 81-87.
Bates, L.S., R.P. Waldren and I.D. Teare, 1973. Rapid determination of free proline for water-stress studies. Plant Soil, 39: 205-207.

DOI: $10.1007 / \mathrm{BF} 00018060$

Behanzin, G.J., E.S. Adjou, A.G. Yessoufou, E.D. Ahoussi and A. Sezan, 2015. Effet des sels de métaux lourds (chlorure de Cobalt et chlorure de Mercure) sur l'activité des hépatocytes. J. Applied Biosci., 83: 7499-7505. DOI: 10.4314/jab.v83i1.4

Bradford, M.M., 1976. A rapid and sensitive method for the quantitation of microgram quantities of protein utilizing the principle of protein-dye binding. Anal. Biochem., 72: 248-254. DOI: 10.1016/0003-2697(76)90527-3

Chatterjee, C., B.K. Dubey, P. Sinha and P. Srivastava, 2004. Detrimental effects of lead phytotoxicity on growth, yield and metabolism of rice. Commun. Soil Sci. Plant Anal., 35: 255-265. DOI: $10.1081 / C S S-120027648$

Chen, X.Y., X.F. He, X.M. Luo, Y.L. Yu and Q. Lino et al., 2002. Physiological mechanism of plant roots exposed to Cadmium. Chemosphere, 50: 789-793. DOI: 10.1016/S0045-6535(02)00220-5

Chen, J., C. Zhu, L.P. Li, Z.Y. Sun and X.B. Pan, 2007. Effects of exogenous salicylic acid on growth and $\mathrm{H}_{2} \mathrm{O}_{2}$-metabolizing enzymes in rice seedlings under lead stress. J. Environ. Sci., 19: 44-49. DOI: 10.1016/S1001-0742(07)60007-2

Ernst, W.H.O., J.A.C. Veklej and H. Schat, 1992. Metal tolerance in plants. Plant Biol., 41: 229-248. DOI: $10.1111 / \mathrm{j} .1438-8677.1992 . t b 01332 . \mathrm{x}$

Fargo, M.E. and W.A. Mullen, 1979. Plants which accumulate metals. Part IV. A possible copperproline complex from the roots of Armeria maritima. Inorg. Chim. Acta, 32: L93-L94. DOI: 10.1016/S0020-1693(00)91627-X

Gopal, R. and A.H. Rizvi, 2008. Excess lead alters growth, metabolism and translocation of certain nutrient in radish. Chemosphere, 70: 1539-1544.

Gupta, M., U.N. Rai, R.D. Tripathi and P. Chandra, 1995. Lead induced changes in glutathione and phytochelatin in Hydrilla verticillata (1. f.) Royle. Chemosphere, 30: 2011-2020. DOI: 10.1016/0045-6535(95)00075-J

Hiscox, J.D. and G.F. Israelsam, 1979. A method for the extraction of chlorophyll from leaf tissue without maceration. Can. J. Bot., 57: 1332-1334. DOI: $10.1139 / \mathrm{b} 79-163$

Kosobrukhov, A., I. Knyazeva and V. Mudrik, 2004. Plantago major plants responses to increase content of lead in soils: Growth and photosynthesis. Plant Growth Regul., 42: 145-151. DOI: 10.1023/B:GROW.0000017490.59607.6b 
Kozlowski, R., J. Kozlowska, L. Grabowska, J. Mankowski and B. Szpakowska, 2003. Métaux lourds dans l'environnement: Menaces et possibilités de riposte. Institut des Fibres Naturelles, Poznan, Pologne.

Krupa, Z. and T. Bazynski, 1995. Some aspects of heavy metals toxicity towards photosynthetic apparatusdirect and indirect effects on light and dark reactions. Acta Physiol. Plant., 17: 177-190.

Małecka, A., A. Piechalak, I. Morkunas and B. Tomaszewska, 2008. Accumulation of lead in root cells of Pisum sativum. Acta Physiol. Plantarum, 30: 629-629. DOI: 10.1007/s11738-008-0159-1

Mehta, S.K. and J.P. Gaur, 1999. Heavy-metal-induced proline accumulation and its role in ameliorating metal toxicity in Chlorella vulgaris. New Phytol., 143: 253-259. DOI: $10.1046 / j .1469-8137.1999 .00447 . x$

Mesmar, M.N. and K. Jaber, 1991. The toxic effect of lead on seed germination, growth, chlorophyll and protein contents of wheat and lens. Acta Biol. Hung., 42: 331-344. PMID: 1841484

Minitab reference manual, release 12.21 for windows, 1998 P.A. state college, Minitab, 1047 p.

Mishra, A.A. and M.A. Choudhuri, 1998. Amelioration of lead and mercury effects on germination and rice seedling growth by antioxidants. Biol. Plantarum, 41: 469-473. DOI: 10.1023/A:1001871015773

Mishra, S., S. Srivastava, R.D. Tripathi, R. Kumar and C.S. Seth et al., 2006. Lead detoxification by coontail (Ceratophyllum demersum L.) involves induction of phytochelatins and antioxidant system in response to its accumulation. Chemosphere, 65: 1027-1039.

DOI: 10.1016/j.chemosphere.2006.03.033

Mohan, B.S. and B.B. Hosetti., 1997. Potential phytotoxicity of lead and cadmium to lemna minor grown in sewage stabilization ponds. Environ. Poll., 98: 233-238. DOI: 10.1016/S0269-7491(97)00125-5

Moreno-Casseles, J., R. Moraln, A. Perez Espinosa and M.D. Peres Murcia, 2000. Cadmium accumulation and distribution in Cucumber plant. J. Plant Nutr. 23: 243-250. DOI: 10.1080/01904160009382011

Mourato, M.P., I.N. Moreira, I. Leitão, F.R. Pinto and J.R. Sales et al., 2015. Effect of heavy metals in plants of the genus Brassica. Int. J. Mol. Sci., 16: 17975-17998. DOI: 10.3390/ijms160817975

Nagajyoti, P., K. Lee and T. Sreekanth, 2010. Heavy metals, occurrence and toxicity for plants: A review. Environ. Chem. Lett., 8: 199-216. DOI: $10.1007 / \mathrm{s} 10311-010-0297-8$

Padjama, K., D.P.K. Prassad and A.R.K. Prassad, 1990. Inhibition of chlorophyll synthesis in Phaseolus vulgaris L. seedlings by cadmium acetate. Photosynthetica, 24: 399-405.
Palozza, P. and N.I. Krinsky, 1999. Astaxanthin and canthaxanthin are potent antioxidants in a membrane model. Arch Biochem. Biophys., 29: 291-295. PMID: 1497349

Piechalak, A., B. Tomaszewska, D. Baralkiewicz and A. Malecká, 2002. Accumulation and detoxification of lead ions in legumes. Phytochemistry, 60: 153-162. DOI: 10.1016/S0031-9422(02)00067-5

Prasad, M.N.V. and J. Hagemeyer, 1999. Heavy Metal Stress in Plants: From Molecules to Ecosystems. 1st Edn., Springer, Berlin, pp: 401.

Prassad, M., P. Malec, A. Waloszek, M. Bojko and K. Strzalka, 2001. Physiological responses of Lemna trisulca L. (duckweed) to cadmium and copper bioaccumulation. Plant Sci., 161: 881-889. DOI: 10.1016/S0168-9452(01)00478-2

Qureshi, M.I., M. Israr, M.Z. Abdin and M. Iqbal, 2005. Responses of Artemisia annua L. to lead and saltinduced oxidative stress. Environ. Exp. Bot., 53: 185-193. DOI: 10.1016/j.envexpbot.2004.03.014

Raskin, I., P.BA.N Kumar, S. Dushenkov and D.E. Salt, 1994. Bioconcentration of heavy metals by plants. Curr. Opin. Biotechnol., 5: 285-290. DOI: 10.1016/0958-1669(94)90030-2

Rauser, W.E., 1999. Phytochelatins and related peptides: Structure, biosynthesis and function. Plant Physiol., 109: 1141-1149. DOI: 10.1104/pp.109.4.1141

Sandquiest, E.A., K. Briviba and H. Sies, 1994. Singlet oxygen quenching by carotenoids. Meth. Enzymol., 234: 354-366. DOI: 10.1016/0076-6879(94)34108-7

Saxena, A., D.K. Saxena and H.S. Srivastava, 2003. The Influence of Glutathione on Physiological Effects of Lead and its Accumulation in Moss Sphagnum Squarrosum. Water Air Soil Pollut., 143: 351-361. DOI: $10.1023 / \mathrm{A}: 1022856807592$

Siddiqui, M.M., B.H. Abbasi, N. Ahmad, M. Ali and T. Mahmood, 2014. Toxic effects of heavy metals $(\mathrm{Cd}, \mathrm{Cr}$ and $\mathrm{Pb})$ on seed germination and growth and DPPH-scavenging activity in Brassica rapa var. Turnip. Toxicol. Ind. Health 30: 238-249. DOI: $10.1177 / 0748233712452605$

Semmadi, A, 1989. The atmospheric pollution (Global pollution, Fluor and Lead) on vegetation of Annaba country. PhD Thesis, Pierre et Marie Currie University, Paris.

Seregin, I.V. and VB. Ivanov, 2001. Physiological aspects of cadmium and lead toxic effects on higher plants. Russ. J. Plant Physiol., 48: 523-544. DOI: $10.1023 / \mathrm{A}: 1016719901147$

Seregin, I.V., V.M. Pekhov and V.B. Ivanov, 2002. Plasmolysis as a tool to reveal lead localization in the apoplast of root cells. Russ. J. Plant Physiol., 49: 283-285. DOI: 10.1023/A:1014822127865 
Sharma, P. and R.D. Shanker, 2005. Lead toxicity in plants. Braz. J. Plant. Physiol., 17: 1-26. DOI: 10.1590/S1677-04202005000100004

Shirafew, B. and D.A. Baker, 1996. An evaluation of drought screening techniques for Eragrostis tef. Trop. Sci., 36: 74-85.

Singh, R.P., R.D. Tripathi, S.K. Sinka, R. Mahesshwari and H.S. Srivastava, 1997. Response of higher plants to lead contaminated environment. Chemosphere, 34: 2464-2493. DOI: $10.1016 / \mathrm{S} 0045-6535(97) 00087-8$

Tomulescu, I.E., V. Radoviciu, N.A. Merca and A. Tuduce, 2004. Effects of copper, zinc and lead and their combinations on the germination capacity of two cereals. J. Agric. Sci., 15: 39-42.

Van Assche, F. and H. Clijsters, 1990. Effects of metals on enzyme activity in plants. Plant Cell Environ., 13: 195-206. DOI: 10.1111/j.1365-3040.1990.tb01304.x

Viehweger, K., 2014. How plants cope with heavy metals. Bot. Stud., 55: 1-12. DOI: 10.1186/1999-3110-55-35

Vodnik, D., G. Jentschke, E. Fritz, N. Gogala and D.L. Godbold, 1999. Root-applied cytokinin reduces lead uptake and affects its distribution in Norway spruce seedlings. Physiol. Plant., 106: 75-81. DOI: 10.1034/j.1399-3054.1999.106111.x
Weckbeker, G. and J.G. Cory, 1998. Ribonucleotide reductase activity and growth of glutathionedepleted mouse leukemia L1210 cells in vitro. Cancer Lett., 40: 257-264. DOI: $10.1016 / 0304-3835(88) 90084-5$

Wierzbicka, M. and J. Obidzinska, 1998. The effect of lead on seed imbibition and germination in different plant species. Plant Sci., 137: 155-171. DOI: $10.1016 / \mathrm{S} 0168-9452(98) 00138-1$

Wolinska, D., Z. Krupa and A. Tukendorf, 1980. Photosynthetic activities of cadmium-treated tomato plants. Physiol. Plant., 48: 365-370. DOI: $10.1111 / \mathrm{j} .1399-3054.1980 . t b 03269 . \mathrm{x}$

Wozny, A.J., J. Schneider and E.A. Gwozdz, 1995. The effects of lead and kinetin on greening barley leaves. Biol. Plant., 37: 541-552.

DOI: $10.1007 / \mathrm{BF} 02908836$

Xiong, Z.T., 1997. Bioaccumulation and physiological effect of excess lead in a read side pioneers species. Sonchus oleraceus L. Environ. Poll., 97: 275-279. DOI: 10.1016/S0269-7491(97)00086-9

Xiong, Z.T., F. Zhao and M. Li, 2006. Lead toxicity in Brassica pekinensis Rupr.: Effect on nitrate assimilation and growth. Environ. Toxicol., 21: 147-153. DOI: $10.1002 /$ tox. 20167 